\title{
Evaluation of the fatigue macro-cracking behavior of crumb rubber modified bituminous mixes
}

\author{
F. Moreno-Navarro ${ }^{\mathrm{a}} \bowtie$, M. C. Rubio-Gámez ${ }^{\mathrm{a}}$, E. Tomás-Fortún ${ }^{\mathrm{b}}$, \\ F. Valor-Hernández ${ }^{b}, A$. Ramírez-Rodriguez ${ }^{\mathrm{c}}$ \\ a. Universidad de Granada (Granada, Spain) \\ b. CIESM-INTEVIA (Madrid, Spain) \\ c. Sacyr (Madrid, Spain) \\ $\triangle$ fmoreno@ugr.es
}

\author{
Received 11 September 2013 \\ Accepted 3 February 2014
}

Available on line 1 August 2014

\begin{abstract}
The use of crumb rubber modified bitumen (CRMB) in asphalt mixes is a road engineering technology that has become increasingly important in recent years. Given the many economic and environmental benefits of this type of binder, the goal is to give CRMB the same level of performance as conventional polymermodified bitumen. The appearance and propagation of cracks due to fatigue phenomena is one of the most common distresses affecting road pavements. Since crumb rubber enhances the mechanical properties of asphalt mixes, it can provide a viable solution for fatigue cracking. This paper presents the results of a comparative analysis of the fatigue-cracking behavior of asphalt mixtures manufactured with crumb rubber modified bitumen and polymer-modified bitumen.
\end{abstract}

KEYWORDS: Asphalt mixes; Crumb rubber; Fatigue cracking; Four-point bending test

Citation / Citar como: Moreno-Navarro, F.; Rubio-Gámez, M.C.; Tomás-Fortún, E.; Valor-Hernández, F.; Ramírez-Rodríguez, A. (2014). Evaluation of the fatigue macro-cracking behavior of crumb rubber modified bituminous mixes. Mater. Construcc. 64 [315], e027. http://dx.doi.org/10.3989/mc.2014.07913.

RESUMEN: Evaluación del comportamiento a macro-fisuración por fatiga de mezclas bituminosas modificadas con polvo de neumático. El empleo de betunes modificados con polvo de neumático usado en la fabricación de mezclas bituminosas es una de las técnicas que mayor auge está teniendo en los últimos años en la ingeniería de carreteras. Dadas sus grandes ventajas económicas y ambientales, este tipo de ligantes pretende conseguir prestaciones similares a la de los betunes modificados con polímeros utilizados habitualmente. La aparición de fisuras debido a fenómenos de fatiga es una de las patologías más comunes en firmes de carretera. Debido a las mejoras de las propiedades mecánicas del betún aportadas tras la incorporación de polvo de neumático, las mezclas fabricadas con estos ligantes se postulan como una posible solución a dicho problema. En este artículo se lleva a cabo un análisis comparativo del comportamiento a fisuración por fatiga realizado sobre mezclas bituminosas fabricadas con betún modificado con polvo de neumático y con polímeros.

PALABRAS CLAVE: Mezclas bituminosas; Polvo de neumático; Fisuración por fatiga; Ensayo de flexión en 4 puntos

Copyright: (C) 2014 CSIC. This is an open-access article distributed under the terms of the Creative Commons Attribution-Non Commercial (by-nc) Spain 3.0 License. 


\section{INTRODUCTION}

Fatigue cracking is one of the most common road pavement distresses affecting pavement surfaces throughout the world. In fact, its negative impact on roads can prematurely end their service life. It is thus crucial to design materials, capable of withstanding the stresses and strains produced by cyclic traffic loads and temperature changes, which are the main causes of fatigue cracking (1).

Bituminous mixes are the most widely used material in road construction (2). For this reason, the enhancement of their mechanical performance contributes to the development of longer lasting pavement surfaces. Nevertheless, despite the many studies carried out around this distress, fatigue cracking is one of the main issues in relation to the researches which are developing in road engineering. Thus, there is a need for an in-depth study of why and how cracks appear and propagate, in order to improve the mechanical performance of bituminous mixes for a wide range of environmental conditions and for different types of load.

The addition of crumb rubber modifier (CRM) from end-of-life tires to bituminous mixes (by the dry process as well as the wet process) enhances the mechanical performance of these mixes and their resistance to fatigue and deformation, which are the main causes of cracking (3). The reaction between the CRM and bitumen at a certain temperature increases the viscosity of the bitumen and modifies its rheological properties, thus giving it greater elasticity and lower thermal susceptibility. Since this makes the CRM mix more resistant to fatigue cracking, the addition of crumb rubber modifier is an effective way to delay cracking and thus prolong the service life of the pavement surface (4-6).

Given these reasons as well as the many advantages of recycling end-of-life tires, great efforts are currently being made to develop high-performance bitumens modified with crumb rubber. For this purpose, certain quantities of crumb rubber are added to conventional bitumen in order to improve its performance and thus lengthen the service life of the mix. The objective is for this binder to achieve a performance similar to that of the polymermodified bitumens (SBS and EVA), which are currently in use.

This research evaluates the fatigue-cracking strength of a crumb rubber wet-process mix, containing high-viscosity rubber-modified bitumen (HVRMB). These results were compared with those obtained for other mixes of the same composition, but which were manufactured with highperformance polymer-modified bitumen (BM3b). This study is focused on the evaluation of the resistance of the material to the propagation of macro-cracks (an aspect rarely studied during the evaluation of the fatigue behavior of asphalt mixes (7)) instead of the fatigue-resistance properties of CRM mixes, which have been analyzed and demonstrated by various authors (8). For this purpose, a correlation of the mechanical response of the materials (stress values and deformations) and their deterioration (measured with an image monitoring system and optic sensors) has been made.

\section{METHODOLOGY}

\subsection{Materials}

Two of the most commonly mixes used to mitigate cracking in pavement surfaces have been studied in this research: sand-asphalt (S-A) and stone mastic asphalt (SMA) $(9,10)$. All mixes were manufactured with the same filler (cement) and had the same aggregate type (limestone). Thus, this study focused on the evaluation of the effect of the two types of binder used: (i) polymer-modified bitumen (BM3b); (ii) high-viscosity rubber-modified bitumen via the wet process (HVRMB). The characteristics of the mix components are listed in Tables 1 and 2.

The grain sizes used to manufacture the S-A and SMA mixes are shown in Figure 1. It should be underlined that the mineral skeletons of the HVRMB and BM $3 \mathrm{~b}$ mixes were the same and that the mixes only differed in the type and content of the binder. Table 3 lists the properties of the mixes in regards to moisture sensitivity and plastic deformations.

\subsection{Experimental design}

Mix resistance to fatigue cracking was evaluated with the 4-point bending test. The dimensions of the test specimens were $410 \times 50 \times 50 \mathrm{~mm}$. The experimental device used had a high-resolution image capturing system as well as an optic sensor, which monitored deformations and thus facilitated the analysis of the cracking process in the specimens. In this way, the force and deformation values occurred during each load cycle as well as the propagation of the macro-crack, was recorded inside a representative volume where the cracking process takes place. Furthermore, two movement indicators were placed near the macro-crack (on both sides of the crack and underneath it), which are used to measure the deformations produced in the lips of the crack (Figure 2).

The test specimens had a triangular notch located in the center $(10 \mathrm{~mm}$ high and $10 \mathrm{~mm}$ long at the base). This made it possible to induce the appearance of the macro-crack in the area monitored by the camera (Figure 2). The failure criterion signaling the end of the test was when the macro-crack attained a length of $25 \mathrm{~mm}$. When this value was reached, 
TABLE 1. Aggregate properties

\begin{tabular}{lc}
\hline Test & Result \\
\hline Flakiness index (\%) (UNE-EN 933-3) & 2 \\
Resistance to fragmentation (UNE-EN1097-2) & 20 \\
Percent of fractured face (\%) (UNE-EN 933-5) & 100 \\
Cleaning of coarse aggregate (organic impurity content) (Annex C, UNE 146130) & 0.01 \\
Sand equivalent (UNE-EN 933-8) & 72 \\
\hline
\end{tabular}

TABLE 2. Bitumen properties

\begin{tabular}{|c|c|c|c|}
\hline \multicolumn{2}{|l|}{ Bitumen } & BM3b & HVRMB \\
\hline \multicolumn{2}{|l|}{ Penetration (UNE-EN 1426) (mm) } & 54 & 66 \\
\hline \multicolumn{2}{|c|}{ Softening point, ring and ball method (UNE-EN 1427) $\left({ }^{\circ} \mathrm{C}\right)$} & 68.1 & 70.0 \\
\hline \multicolumn{2}{|c|}{ Fragility temperature (Fraas method) (UNE-EN 12593) $\left({ }^{\circ} \mathrm{C}\right)$} & -17 & -15 \\
\hline \multicolumn{2}{|c|}{ Elastic recovery at $25^{\circ} \mathrm{C}(\mathrm{NLT} 329)(\%)$} & 73 & 80 \\
\hline \multicolumn{2}{|c|}{ Force ductility at $5{ }^{\circ} \mathrm{C}(\mathrm{UNE} 13589)\left(\mathrm{J} / \mathrm{cm}^{2}\right)$} & 27 & 8 \\
\hline \multicolumn{2}{|c|}{ Flash and fire point (UNE-EN ISO 2592) $\left({ }^{\circ} \mathrm{C}\right)$} & 258 & 268 \\
\hline \multirow{2}{*}{ Storage stability (UNE-EN 13399) } & Ring-ball $\left({ }^{\circ} \mathrm{C}\right)$ & 0.2 & 1.4 \\
\hline & Penetration difference $(\mathrm{mm})$ & 0 & 0 \\
\hline
\end{tabular}

Table 3. Properties of the mixes

\begin{tabular}{|c|c|c|c|c|c|}
\hline Mix & $\begin{array}{c}\text { Binder } \\
\text { content }(\%) \\
\end{array}$ & $\begin{array}{c}\text { Apparent } \\
\text { density }\left(\mathrm{Kg} / \mathrm{m}^{3}\right)\end{array}$ & $\begin{array}{c}\text { Maximum } \\
\text { density }\left(\mathrm{Kg} / \mathrm{m}^{3}\right)\end{array}$ & Air voids (\%) & $\begin{array}{c}\text { Stiffness at } \\
20^{\circ} \mathrm{C}(\mathrm{MPa})\end{array}$ \\
\hline S-A BM3b & 9 & 2344 & 2364 & 0.8 & 5885 \\
\hline S-A HVRMB & 12 & 2363 & 2428 & 2.7 & 3690 \\
\hline SMA BM3b & 5.5 & 2513 & 2632 & 4.5 & 6885 \\
\hline SMA HVRMB & 5.5 & 2470 & 2582 & 4.3 & 4532 \\
\hline
\end{tabular}

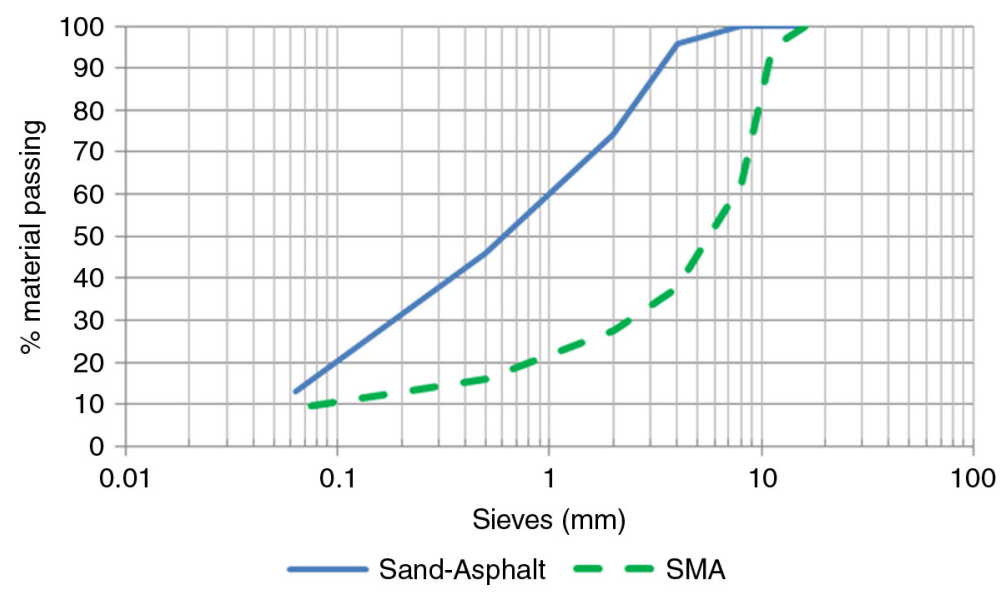

FIGURE 1. Grain sizes of the mixes.

the propagation of the crack became unstable and it was no longer possible to track its behavior. Macrocrack propagation was monitored by digitally measuring the crack as captured in sequential images.
For this purpose, the area where the crack appeared and subsequently spread was painted white.

For a more in-depth study of mix response to cracking, the experiment was carried out inside a climate 

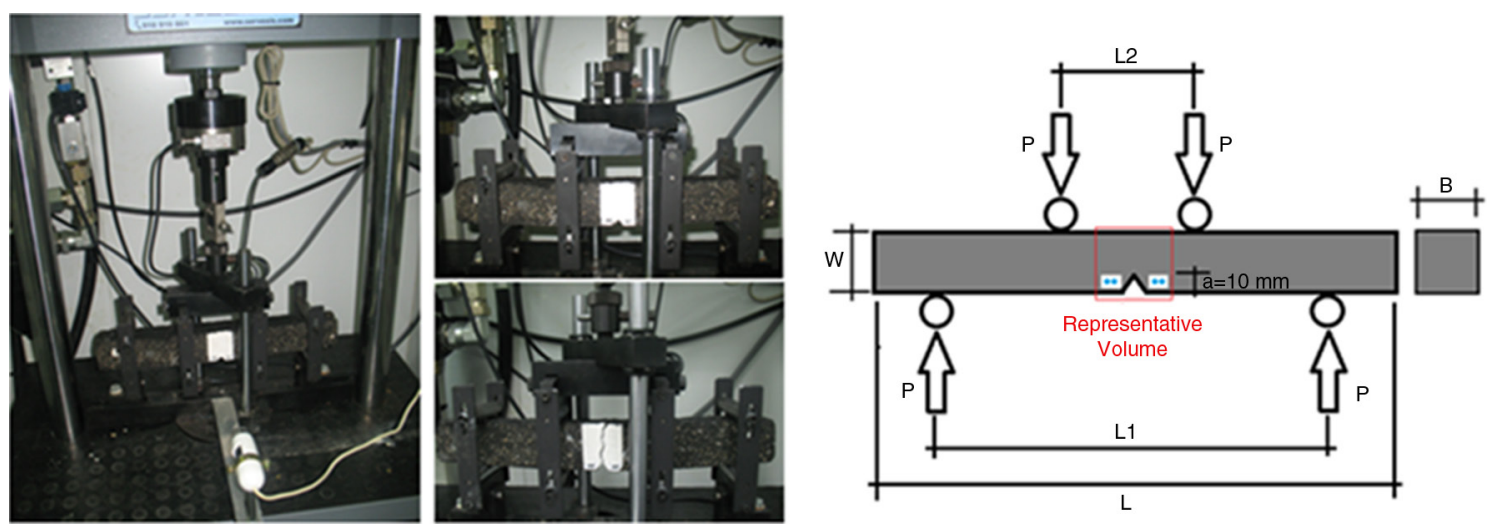

Figure 2. Experimental device and schematic diagram of the test.

chamber. The test conditions for the evaluation of the mixes were a load amplitude of $0.5 \mathrm{~mm}$, a frequency of $10 \mathrm{~Hz}$, and a constant temperature of $20^{\circ} \mathrm{C}$. For a more realistic assessment of the performance of the mixes, the healing effect during the fatigue processes of the materials was taken into account (11-13). For this reason, rest periods were included during the sinusoidal cyclic loading applied as part of the test. Accordingly, there were 1500 loading cycles with a rest period of 150 seconds (the same time period that it took to apply the 1500 cycles). For each type of mix and condition, two specimens were tested.

\section{DISCUSSION OF RESULTS}

\subsection{Sand-Asphalt}

Figure 3 shows the results obtained for the length and width of the crack when the Sand-Asphalt mixes manufactured with BM3b and HVRMB bitumen were tested. As reflected in the figure, in both cases, there is a correspondence between these measurements. More specifically, for the temperature studied, the propagation of the macro-crack is in direct relation to the deformations generated by the crack opening due to the stresses suffered (see Figure 4). For the same loading conditions, the crack width in the HVRMB mix was found to be greater than in the BM3b mix.

The left panel in Figure 5 shows the amount of energy dissipated during the experiment. The values reflect that as the crack propagated throughout the material, less energy was needed for the crack to continue spreading. This occurred because the material decreased in strength as the macro-crack became longer and wider. Consequently, the crack spread more rapidly. The graphs indicate that the $\mathrm{BM} 3 \mathrm{~b}$ mix was found to be more resistant to fatigue cracking because more energy was needed for crack propagation than in the HVRMB mix.

As can be observed in Figure 5 (right panel), there is a linear relation between the length of the macro-crack and the amount of energy dissipated during the experiment. This indicates the correspondence between dissipated energy and the damage to the material. Thus, the amount of dissipated energy can be regarded as optimal design criteria. Within the context of a conventional phenomenological approach (in which loading conditions are related to the number of loading cycles resulting in the failure of the material), the mechanical response of both mixes is similar. Nonetheless,
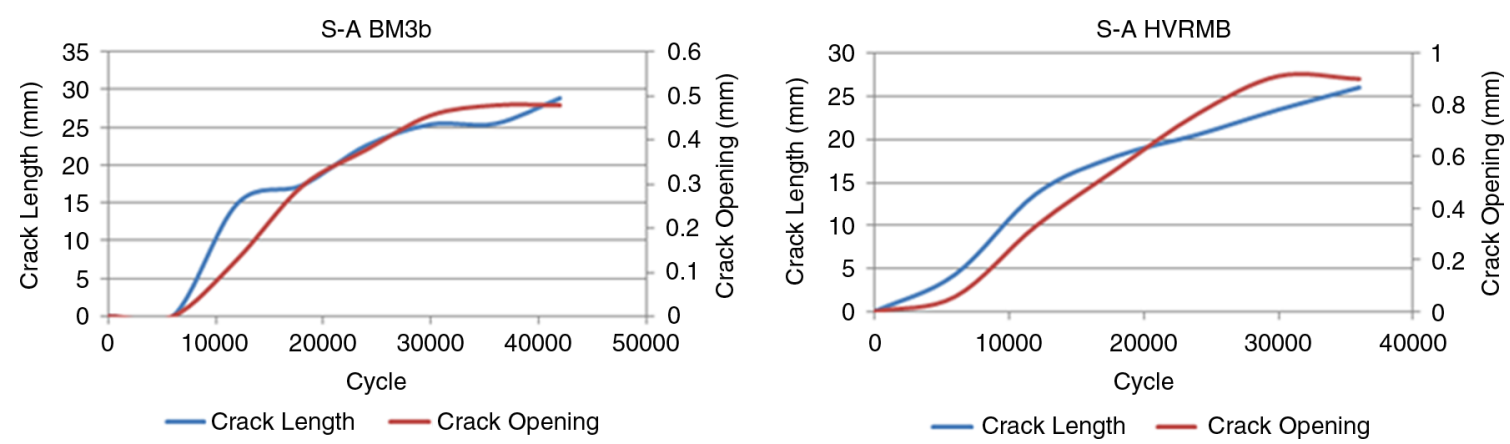

FIGURE 3. Macro-crack length and opening for the Sand-Asphalt mixes. 


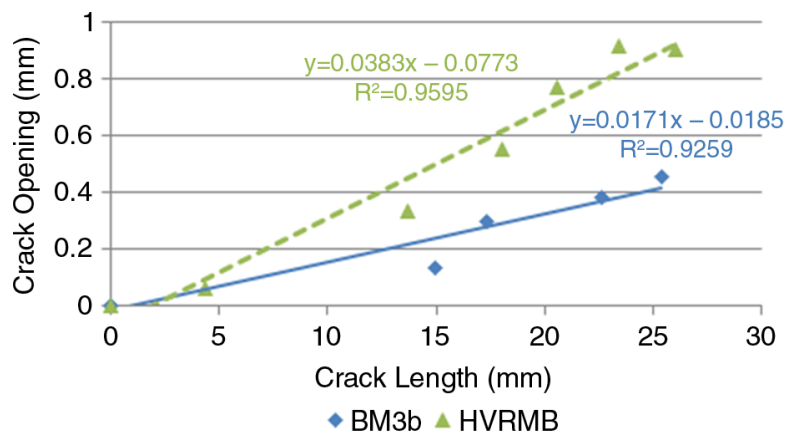

FIGURE 4. Relation between macro-crack opening and length in the Sand-Asphalt mixes.

from the perspective of dissipated energy, the BM3b mixes with SBS polymers were found to be more crack-resistant than the HVRMB mixes with crumb rubber. Figure 6 shows images of the macrocrack propagation in both materials.

\subsection{SMA}

As with the previous mixes, the opening of the macro-crack was also linearly related to propagation length. However, in this case, the mix with the highest crack resistance was the one with the largest crack opening. Consequently, the width of the crack is not directly related to crack propagation in the material (Figures 7 and 8).

Once more, the results confirmed that during the cracking process, there was a progressive decrease in the amount of dissipated energy (Figure 9, left panel). This occurred because more energy was consumed when the crack first appeared in comparison to the energy consumed during its stable
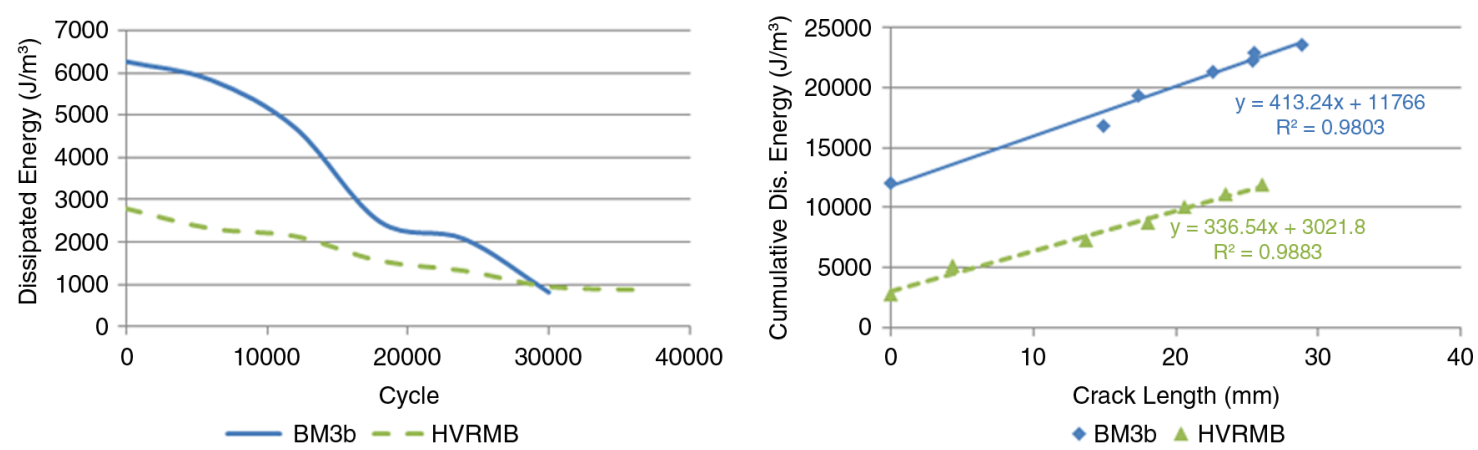

FIGURE 5. Dissipated energy (left panel) in relation to macro-crack propagation (right panel) in the bitumen-bound sand mixes.

\section{S-A BM3b}
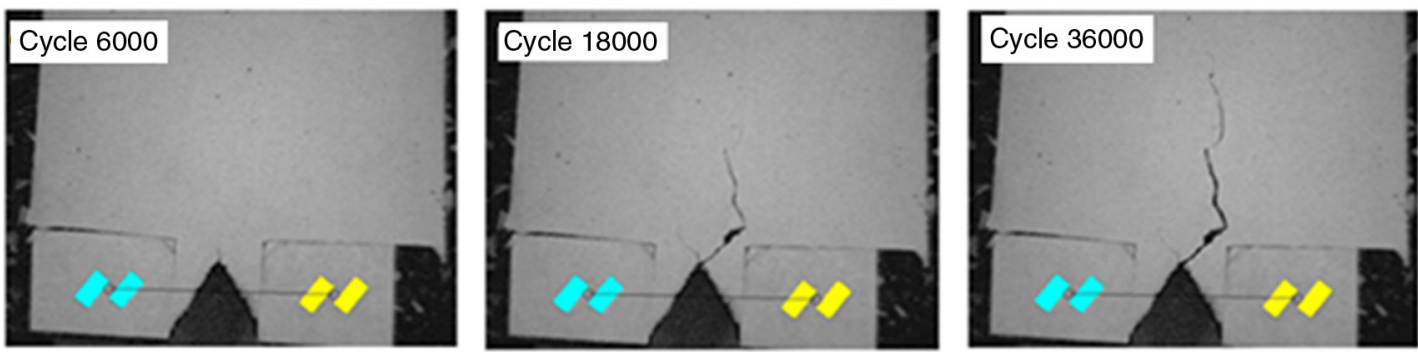

S-A HVRMB
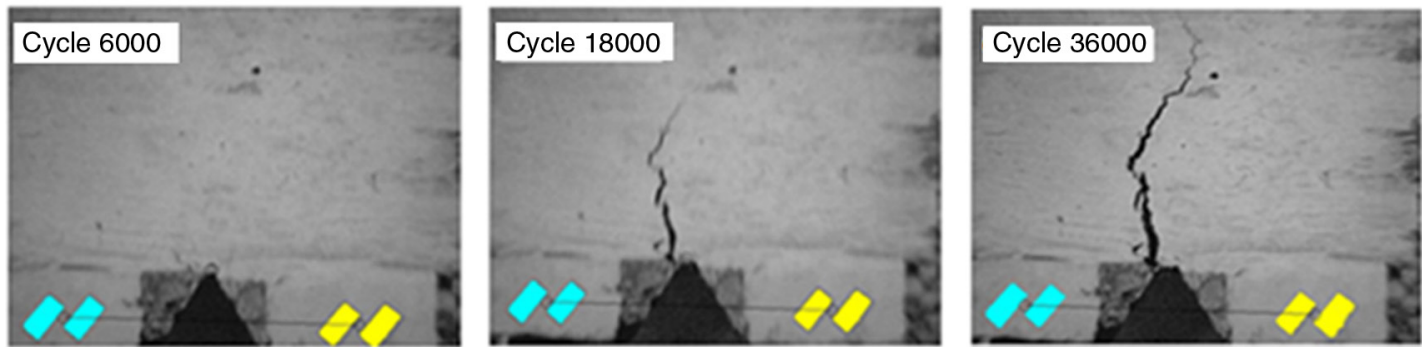

FIGURE 6. Macro-crack development and evolution in the bitumen-bound sand mixes. 
SMA BM3b

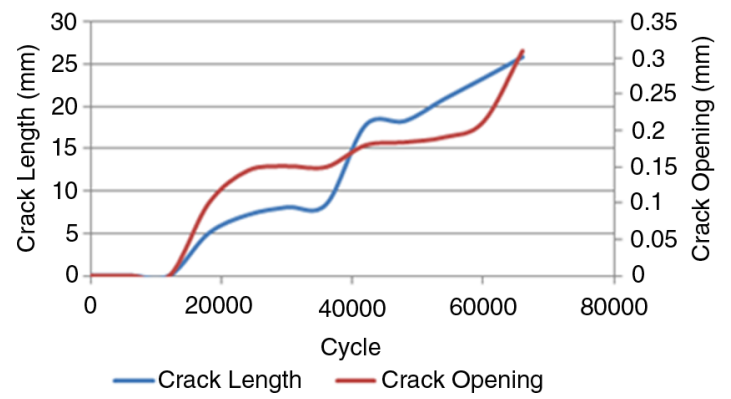

SMA HVRMB

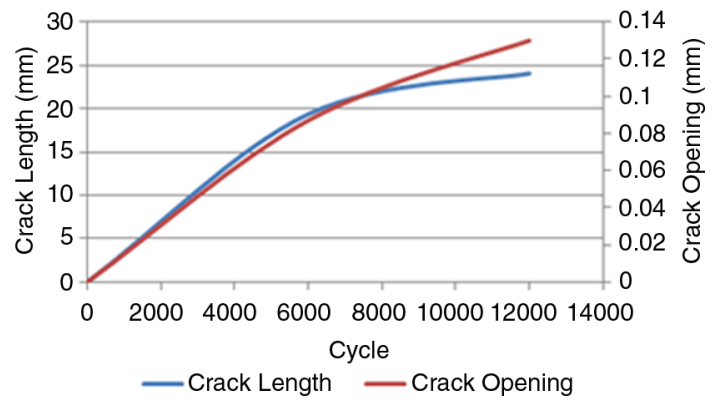

FIGURE 7. Macro-crack length and opening for the stone mastic asphalt mixes.

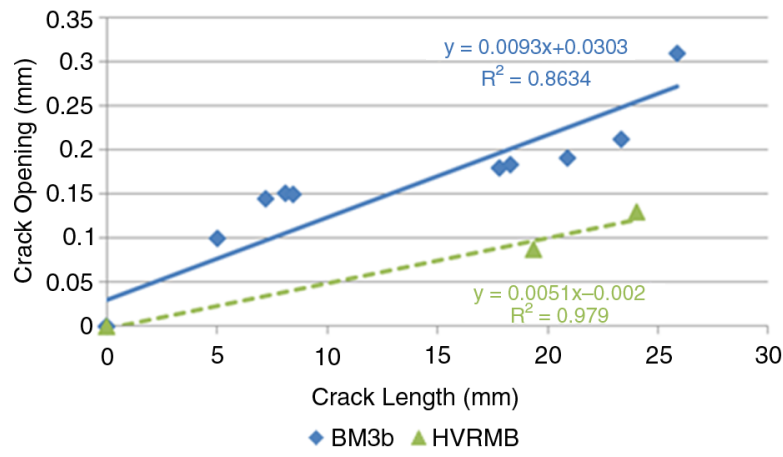

FIGURE 8. Relation between macro-crack opening and length in the SMA mixes.

propagation phase. As in the case of the other mixes, there is a close relation between the cumulative dissipated energy and crack propagation throughout the specimens (Figure 9, right panel). Since the energy required for the crack to appear and subsequently spread throughout the BM3b SMA mix is greater, this signifies that that this mix is more resistant to fatigue cracking.

\section{CONCLUSIONS}

This paper presents the results of a study on the fatigue-cracking strength of two types of bituminous mix (SMA and bitumen-bound sand),

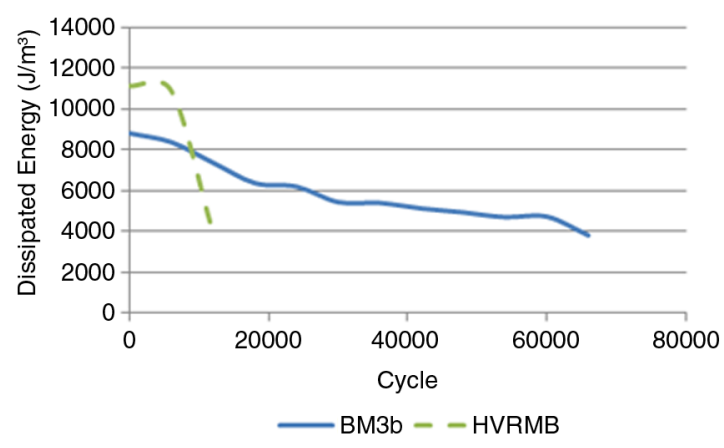

manufactured with crumb-rubber modified bitumen and polymer-modified bitumen with SBS elastomers. The following conclusions can be derived from this research:

The correlation between mix deterioration (crack length and width) and the dissipated energy at the location of the macro-crack can be used to homogeneously evaluate the mechanical strength of the mix. In this sense, the combination of both analyses can be very useful to optimize the laboratory design of mixes since their cracking behavior can be evaluated in each of the phases of the process.

The correlation between the macro-crack opening and its propagation indicates that the deterioration of the specimen advanced, depending on the stresses generated. Nevertheless, the results obtained showed that the damage to the material was not directly related to the width of the macro-crack. The resistance of the material to fatigue cracking thus does not depend on the characteristics of the macrocrack appeared.

Because of the correlation between the energy dissipated and the damage to the material, it was possible to perform an in-depth analysis of the mechanical performance of the materials evaluated. The results of this study showed that the $\mathrm{BM} 3 \mathrm{~b}$ mix was more resistant to the propagation of the macro-crack than the HVRMB mix. Accordingly, despite the fact that the dimensions of the crack and the number of deformation cycles

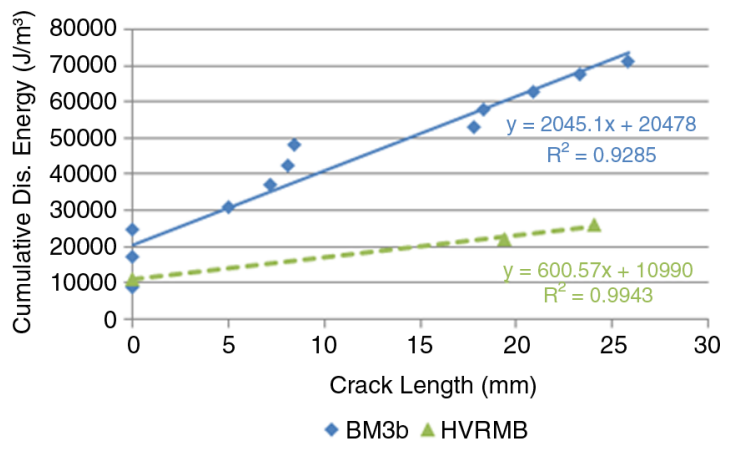

FIGURE 9. Dissipated energy (left panel) in relation to macro-crack propagation (right panel) in the SMA mixes. 
SMA BM3b
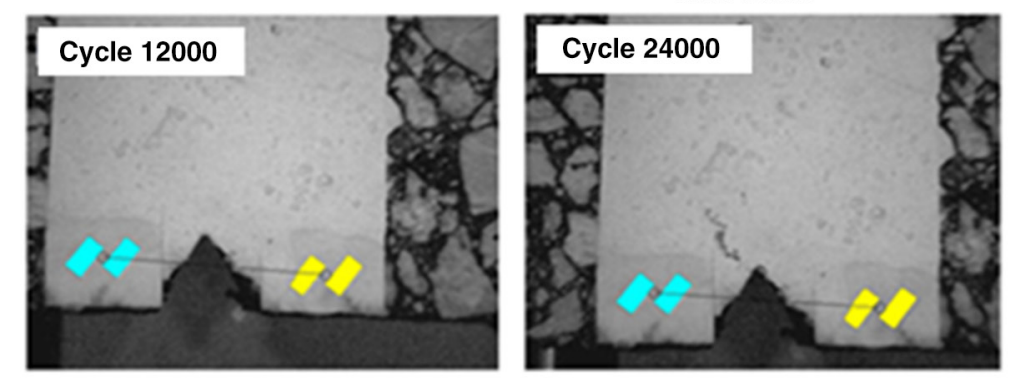

SMA HVRMB
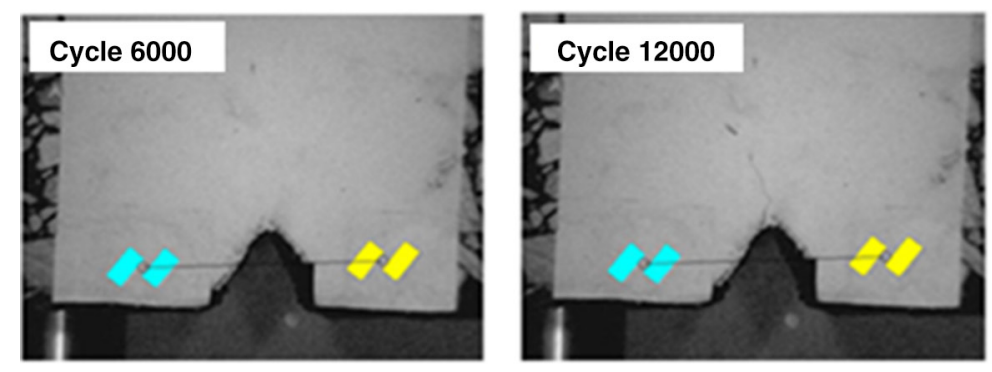
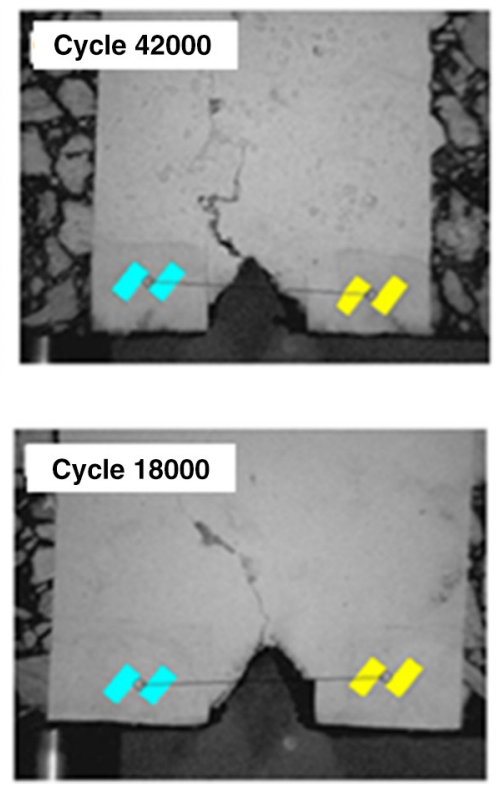

FIGURE 10. Micro-cracking development and evolution in the SMA mixes.

were the same for both binders, the energy required to cause the same level of deterioration in the mix was greater in the BM3b mix.

The analysis of the performance of the two types of mix also showed that the SMA mix was more resistant to fatigue cracking since more energy was required to produce the same level of damage.

\section{ACKNOWLEDGEMENTS}

This research was carried out within the framework of the $\mathrm{R}+\mathrm{D}+\mathrm{i}$ project entitled Proyecto Integrado de Investigación, Desarrollo y Demostración de Tecnologías para la aplicación de neumáticos fuera de uso en firmes de carretera resistentes a la propagación de grietas (ref. IDI-20091076), funded by the Center for Industrial Technological Development (CDTI) of the Ministry of Science and Innovation in Spain.

\section{REFERENCES}

1. Colombier, G. (1997) Cracking in pavements: nature and origin of cracks. Prevention of Reflective Cracking in Pavements - RILEM Report 18. Edited by Vanelstraete A. and Franckien L., 1-15.

2. European Asphalt Pavement Association, EAPA (2012) Asphalt in Figures 2010. <http://www.eapa.org> (Aug. 21, 2012).

3. Ruiz, A. (2010) Mezclas con caucho de neumáticos. Mezclas Bituminosas: dosificación, fabricación, puesta en obra y control de calidad, Course given in Barcelona.
4. Mamlouk, M.; Mobasher, B. (2004) Cracking resistance of asphalt rubber mix versus hot-mix asphalt, Road Materials and Pavement Design, 5 [4], 435-451. http://dx.doi.org/ 10.1080/14680629.2004.9689980.

5. Mull, M. A.; Othman, A.; Mohammad, L. (2005) Fatigue crack propagation analysis of chemically modified crumb rubber asphalt mixtures, Journal of Elastomers and Plastics, 37, 73-86. http://dx.doi.org/10.1177/0095244305049898.

6. Abojaradeh, M.; Jrew, B.; Ghragheer, F.; Kaloush, K. E.; Abojaradeh, D. (2010) Cracking characteristic of asphalt rubber mixtures, Jordan Journal of Civil Engineering, 4, 205-210.

7. Di Benedetto, H. (2013) Fatigue and other phenomena during cyclic loading of bituminous materials, Keynote delivered at the $5^{\text {th }}$ EATA Conference, European Asphalt Technology Association, Braunschweig, Germany.

8. Sibal, A.; Das, A.; Pandey, B. B. (2000) Flexural fatigue characteristics of asphalt concrete with crumb rubber, International Journal of Pavement Engineering, 1 [2], 119-132. http://dx.doi.org/10.1080/10298430008901701.

9. Centro de Estudios y Experimentación de Obras Públicas, CEDEX (1992) Jornadas sobre Reflexión de Grietas en Carreteras, Madrid.

10. Drüschner, L.; Schäfer, V. (2005) Stone Mastic Asphalt, Asphalt Guide, German Asphalt Association.

11. Bazin, P.; Saunier, J. (1967) Deformability, fatigue and healing properties of asphalt mixes, International Conference on the Structural Design of Asphalt Pavements, Ann Arbor, University of Michigan.

12. Bonnaure, F.P.; Huibers, A.H.J.J.; Boonders, A. (1982) A laboratory investigation of the influence of rest periods on the fatigue characteristics of bituminous mixes, Journal of the Association of Asphalt Paving Technologist, 51, 104-128.

13. Kim, Y.R.; Little, D.N.; Lytton, R.L. (2003) Fatigue and healing characterization of asphalt mixtures, Journal of Materials in Civil Engineering, 15 [1], 75-83. http://dx.doi. org/10.1061/(ASCE)0899-1561(2003)15:1(75). 